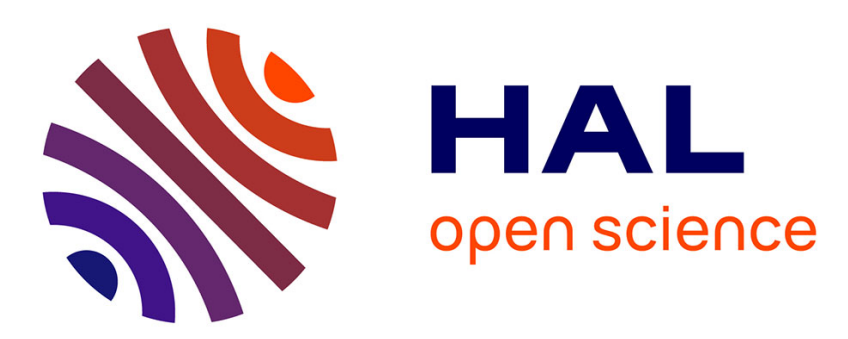

\title{
LBIC INVESTIGATION OF PHOSPHORUS GETTERED MULTICRYSTALLINE SILICON WAFERS
}

I. Perichaud, M. Stemmer, S. Martinuzzi

\section{- To cite this version:}

I. Perichaud, M. Stemmer, S. Martinuzzi. LBIC INVESTIGATION OF PHOSPHORUS GETTERED MULTICRYSTALLINE SILICON WAFERS. Journal de Physique IV Proceedings, 1991, 01 (C6), pp.C6-199-C6-204. 10.1051/jp4:1991630 . jpa-00250716

\section{HAL Id: jpa-00250716 https://hal.science/jpa-00250716}

Submitted on 1 Jan 1991

HAL is a multi-disciplinary open access archive for the deposit and dissemination of scientific research documents, whether they are published or not. The documents may come from teaching and research institutions in France or abroad, or from public or private research centers.
L'archive ouverte pluridisciplinaire HAL, est destinée au dépôt et à la diffusion de documents scientifiques de niveau recherche, publiés ou non, émanant des établissements d'enseignement et de recherche français ou étrangers, des laboratoires publics ou privés. 


\title{
LBIC INVESTIGATION OF PHOSPHORUS GETTERED MULTICRYSTALLINE SILICON WAFERS
}

\author{
I. PERICHAUD, M. STEMMER and S. MARTINUZZI \\ Laboratoire de Photoélectricitédes Semi-conducteurs, Case 231, Faculté des Sciences et Tech- \\ niques de Saint-Jérôme, F-13397 Marseille Cedex 13, France
}

\begin{abstract}
In multicrystalline silicon the interaction of dissolved impurities with extended crystallographic defects limits the effective minority carrier diffusion lengths $\mathrm{L}_{n}$. External gettering by phosphorus diffusion near the surface is used to remove metallic impurities from the bulk of $P$ type silicon wafers. It was found that $L_{n}$ increases drastically after gettering at $850^{\circ} \mathrm{C}$ for 120 or $240 \mathrm{mn}$. SIMS analysis indicates that iron, copper and nickel are accumulated in the phosphorus doped regions and $L B I C$ scan maps at $\lambda=940 \mathrm{~nm}$ indicate that the improvement of $L_{n}$ results of the neutralization of intragrain and grain boundary recombination centers. It is concluded that phosphorus gettering removes dissolved and segregated impurity atoms.
\end{abstract}

\section{Introduction.}

Multicrystalline silicon wafers cut out of cast ingots contain a large variety of extended crystallographic defects like grain boundaries, subgrain boundaries or dislocations. Point defects and impurity atoms are also present like metallic atoms, oxygen and carbon. Metallic impurities and defects which have trapped impurity atoms induce recombination centers, and it is necessary to reduce the impurity-defects interaction in order to improve the electrical properties of this materiel which is essentially devoted to the preparation of low cost solar cells.

Gettering is a means of reducing or eliminating metallic impurities by removing them or localizing them in inactive regions of the wafers. As in solar cells the photovoltaic effect is developped in the bulk of the device, external gettering must be used only. Phosphorus diffusion from a $\mathrm{POCl}_{3}$ source is well known to be an efficient technique of external gettering $1 / 1 /, / 2 /$ which presents the advantage to be one of the preparation steps of cells made with $\mathrm{P}$ type silicon $/ 3 /$.

In a recent paper /4/ we have described the improvements of effective minority carrier diffusion lengths after phosphorus diffusion at $850^{\circ} \mathrm{C}$ for $12 \mathrm{mn}, 120 \mathrm{mn}$ and $240 \mathrm{mn}$. If we had identified some of the gettering impurities like iron, copper and nickel we had not localized the extraction sites of these impurities which could be dissolved in the grains or segregated at the defects. 
The aim of the present work is to verify what regions of the material are concerned by the extraction of impurities : the grain boundaries, the homogeneous region of the grains or the dislocated region of the grains.

\section{Experimental.}

Multicrystalline silicon wafers were cut adjacently in $P$ type cast ingots prepared by Photowatt S.A. /5/. Thanks to the directionnal growth, the density and distribution of extended defects were the same. The grain size was larger than few $\mathrm{mm}$ and the dislocation etch pit density was in the range between $10^{4}$ and $10^{5} \mathrm{~cm}^{-2}$. The thickness of the wafers was about $200 \mu \mathrm{m}$ and carbon and oxygen concentrations are around $4.10^{17} \mathrm{~cm}^{-3}$. The main metallic impurities were iron and copper in concentration below $10^{14} \mathrm{~cm}^{-3}$.

Phosphorus diffusion were carried out at $850^{\circ} \mathrm{C}$ thanks to a $\mathrm{POCl}_{3}$ source. Samples diffused for $12 \mathrm{mn}$ are called standard while longly diffused samples (120 and $240 \mathrm{mn}$ ) are called gettered.

Matched samples of $20 \times 20 \mathrm{~mm}^{2}$ were cut out of the wafers, one $\mathrm{N}^{+}$region was chemically etched, the other was used to realize an array of mesa diodes $(\phi \cong 2 \mathrm{~mm})$ which were revealed at the same place by means of classical photolithography. These diodes allow the measurement of effective minority carrier diffusion lengths $L_{n}$ and the drawing of the LBIC scan maps. The LBIC scans have been done automatically with a focused light spot $(\phi<10$ $\mu \mathrm{m}$ ) at $\lambda=940 \mathrm{~nm}$. Experimental details have been already published $/ 3,6 /$.

Thanks to suited softwares, the LBIC results were represented by a three dimensional scanning or by artificially colored mappings (frontwall view). The color gradations corresponded to different photocurrent intensity.

Endly the samples were chemically etched in order to reveal the extended crystallographic defects.

\section{Results and discussion.}

The variations of $L_{n}$ before and after phosphorus diffusion at $850^{\circ} \mathrm{C}$ for 12,120 and $240 \mathrm{mn}$ are given for 16 diodes by the figure 1 . The effective diffusion lengths increase neatly with the phosphorus diffusion time and reach at least $140 \mu \mathrm{m}$ after the longer treatment. Metallic impurities like iron, copper and nickel are accumulated in the $\mathrm{N}^{+}$region after they are extracted from the bulk, as shown by the figure 2 .

To obtain so high values of $L_{n}$ in the investigated material it is necessary, following the model of El Ghitani et al. $/ 7 /$, that the recombination strength of dislocations be reduced and that the homogeneous regions of the grains be improved. Indeed the effective diffusion length $L_{n}$ is depending on the dislocation density $\mathrm{N}_{\text {dis }}$, of their recombination strength $\mathrm{S}_{\mathrm{d}}$ and on the value of the true diffusion length in the homogeneous region of the grains L. Consequently $L_{n}$ could be expressed by :

$$
L_{n}=f\left(N_{d i s} ; S_{d} ; L\right)
$$




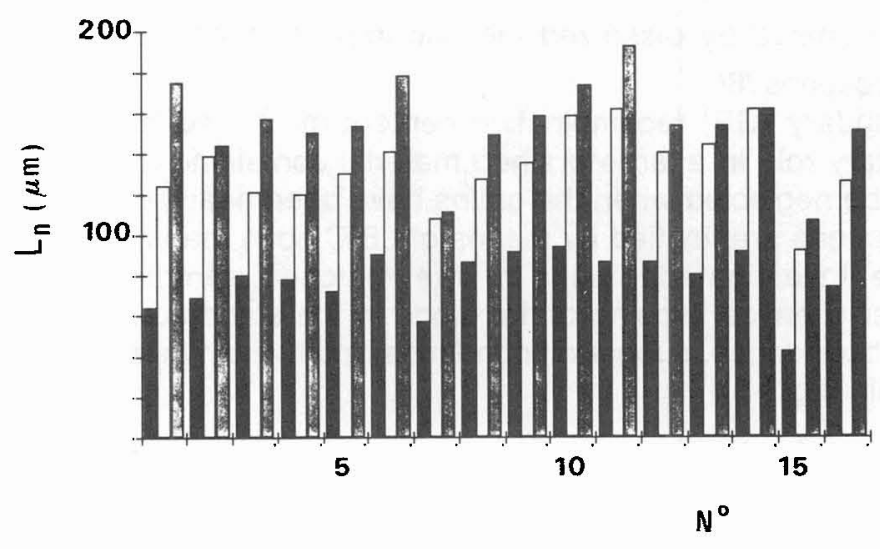

Fig.1. Variation of effective minority carrier diffusion lengths after phosphorus gettering in 16 matched mesa diodes : $\square$ standard sample ; $\square$ gettered for $120 \mathrm{mn}$; gettered for $240 \mathrm{mn}$.

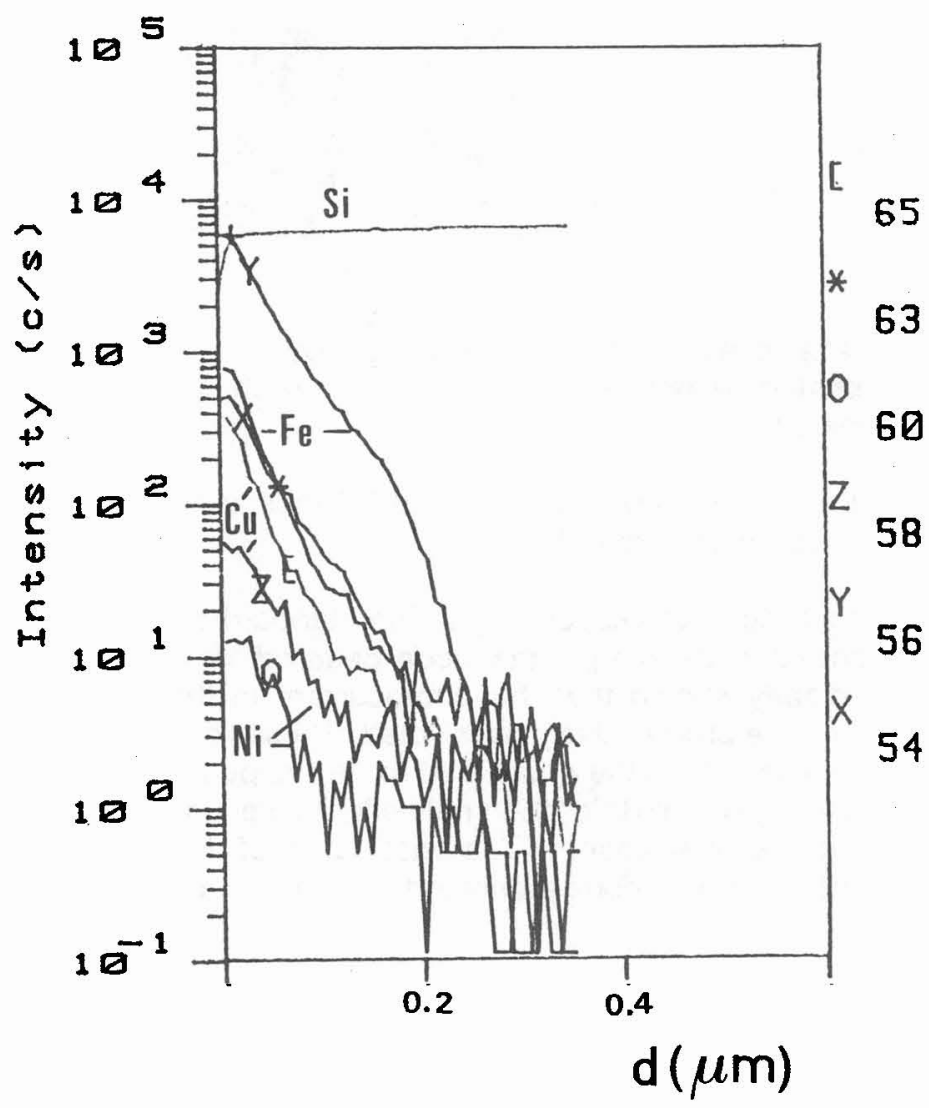

Fig.2. SIMS profiles of a gettered sample $\left(900^{\circ} \mathrm{C}\right.$ $240 \mathrm{mn}$ ) showing the accumulation of $\mathrm{Fe}(54 ; 56)$ $\mathrm{Cu}(63,65)$ and $\mathrm{Ni}(58 ; 60)$ in the $\mathrm{N}^{+}$region. 
where $L$ is essentially limited by dissolved metallic impurities and $S_{d}$ by impurity atoms segregated at the dislocations / 8 /.

In addition, grain boundary (GB) recombination centers must also be neutralized. These defects play a secondary role in a large grained material containing active dislocations but their influence cannot be neglected when the grains have been neatly improved.

The preceding assumptions are verified by means of LBIC scan maps. A typical example is given for one of the investigated diodes of the matched samples. Figure 3-a is a microphotography after chemical etching of the diode in the standard sample which shows the presence of grain boundaries, subgrain boundaries and twins, while dislocation etch pits are revealed in the grain (fig.3-b).

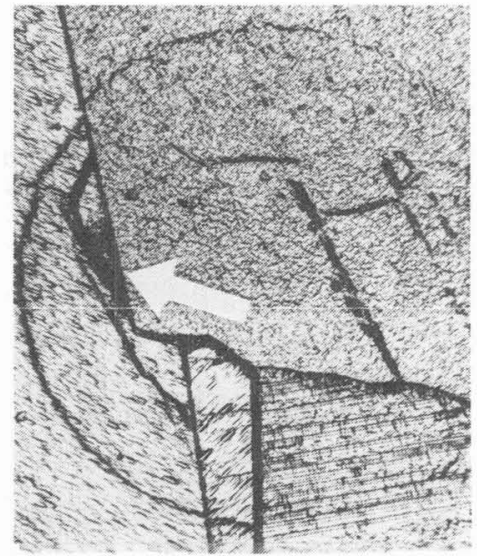

(a)

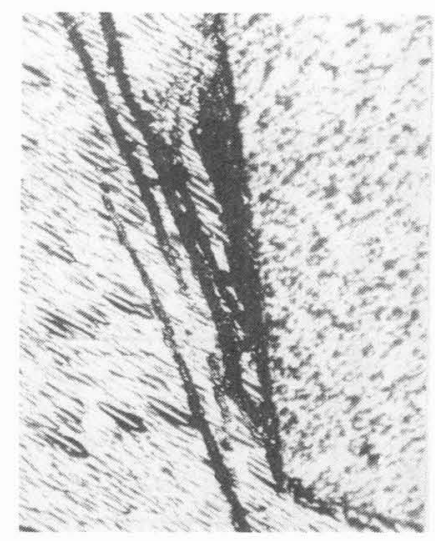

(b)

Fig.3. Microphotography of a diode after chemical etching revealing GBs (3-a). Dislocation etch pits are visible in the highly dislocated regions shown by figure $3 \mathrm{~b}$, which is a magnified part of figure 2-a (indicated by an arrow).

Figure 4 shows the corresponding three dimensional scan map which indicates that the GBs are generally recombining while twin boundaries are not.

Figures 5 are photocurrent mappings in color corresponding to the standard and gettered samples ; figure 5-d is a three dimensional scanning of the diode gettered for $240 \mathrm{mn}$. By comparison with the figure 3 it is clearly shown that the photocurrent in the grains is improved and that the grain boundaries are progressively passivated. These results confirm that the gettering remove dissolved impurities from the grains and those trapped by the GBs. As the GB plane could be considered like a dense dislocation network, phosphorus gettering removes certainly also impurities trapped by dislocations. The passivation of dislocations is also shown by the evolution of the LBIC mapping corresponding to the dislocated region of the figure 3-a. 


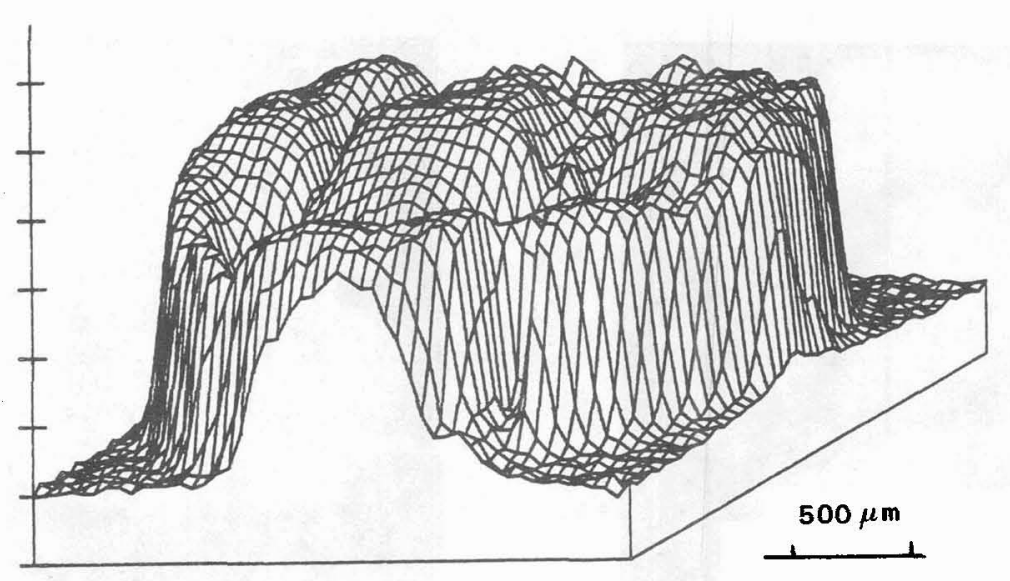

Fig.4. Three dimensional scan map at $\lambda=940 \mathrm{~nm}$ of the diode of figure 2 . The presence of GBs is clearly shown by the photocurrent attenuations.

\section{Conclusion.}

External gettering of impurities by phosphorus diffusion is able to improve multicrystalline silicon wafers which become comparable to $C Z$ crystals. Thanks to the use of LBIC mapping it is clearly shown that this improvement is due to the extraction of metallic impurity atoms dissolved in the grains or trapped by the extended crystallographic defects.

This work was supported by CNRS-PIRSEM and Agence Française pour la Maîtrise de l'Energie.

The authors would like to thank Dr. Sarti, Photowatt S.A. Caen for wafers supplying and gettering treatments.

\section{References.}

/1/ BRONNER G.B., PLUMMER J.D., in Impurity diffusion and gettering in silicon, ed. by

R.B. FAIR, C.W. PEARCE and J. WASHBURN, MRS Symposia Proceedings 36, 1985, p.49.

/2/ KANG J.S. and SCHRODER D.K., J. Appl. Phys.65 (1989) 2974.

/3/ MARTINUZZI S., TORCHIO P., MATHIAN G. and PERICHAUD I., Proc. of $9^{\text {th }}$ European Photovoltaïc Solar Energy Conf. ed. by W. PALZ, Kluwer Acad. Press, Dordrecht, 1989, p.458.

14/ PERICHAUD I. and MARTINUZZI S., Comm. to DES 91, to be published in this journal.

/5/ ANDONOV P., DERVIN P; and LAY P., J. Mater. Res. 5 (1990)

/6/ AMMOR L. and MARTINUZZI S., Solid State Electronics 29,.(1986) 1.

/7/ EL GHITANI H. and MARTINUZZI S., J. of Appl. Phys. 66 (1989) 1723.

/8/ GLAENZER R.H. and A.G. JORDAN, Solid State Electronics 12 (1969) 125. 




(a)

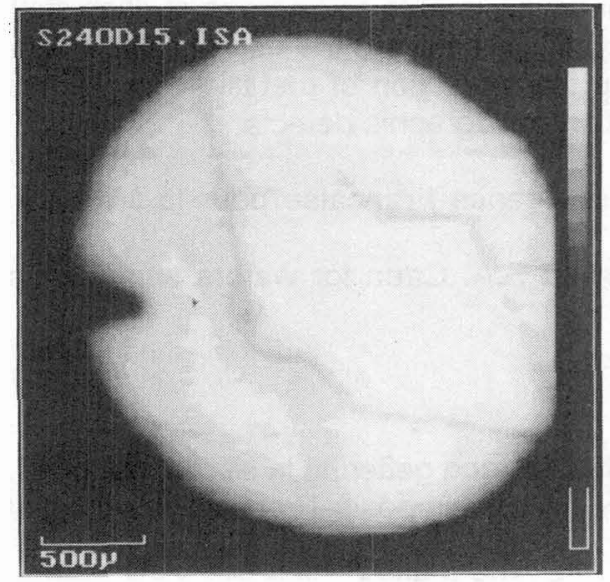

(c)

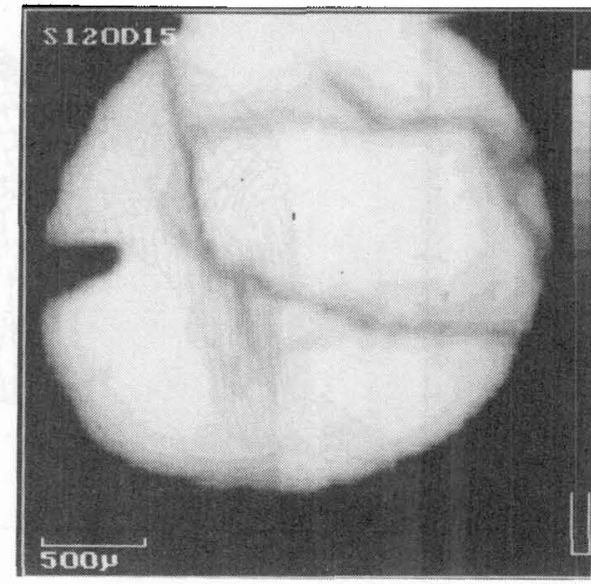

(b)

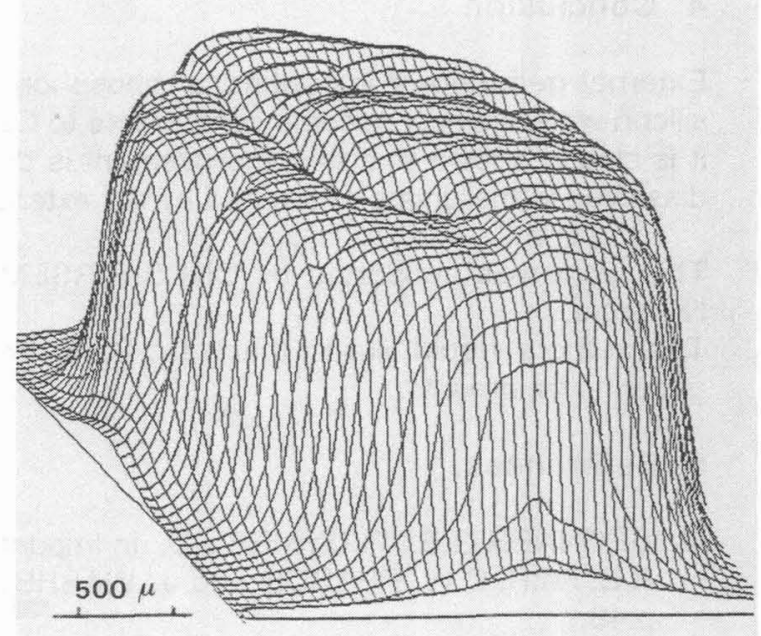

(d)

Fig.5. Front view mapping of photocurrent at $\lambda=940 \mathrm{~nm}$ of diodes made approximately at the same place in matched samples : (a) standard ; (b) gettered for $120 \mathrm{mn}$; (c) gettered for $240 \mathrm{mn}$. In spite of the relative gradation of each picture, it is clearly shown that grains are improved and that grain boundaries are passivated by the removing of impurities.

Three dimensional scanning of the diode gettered for $240 \mathrm{mn}$ confirming the passivation of grains and grain boundaries (d). 